\title{
Dispersal Improvement of a Powder Formulation of Penicillium oxalicum, a Biocontrol Agent of Tomato Wilt
}

\author{
P. Sabuquillo, A. De Cal, and P. Melgarejo, Department of Plant Protection. SGIT-INIA. Madrid, Spain
}

\begin{abstract}
Sabuquillo, P., De Cal, A., and Melgarejo, P. 2005. Dispersal improvement of a powder formulation of Penicillium oxalicum, a biocontrol agent of tomato wilt. Plant Dis. 89:1317-1323.

Sugars, polyalcohols, inorganic salts, and detergents were added to conidia of Penicillium oxalicum at three different points of the production-formulation process to improve water dispersal. Effects also were tested on conidial germination and production. Conidial germination without additives ranged from 51 to $79 \%$. Additives did not reduce conidial germination except for $50 \%$ polyethylene glycol (PEG) 300 and $10 \% \mathrm{CaCl}_{2}$. Sunflower oil and sodium alginate, sucrose $(0.5,15,30$, and $60 \%)$, D-sorbitol (30 and 60\%), glycerol (2, 5, 20, and 30\%), 30\% PEG 300, $\mathrm{CaCl}_{2}(0.01$ to $1 \%)$, Tween 20 (0.01, 0.02, 0.5, and $\left.1 \%\right)$, and Tween $80(0.01$ to $1 \%)$ enhanced conidial germination. Production without additives ranged from 0.57 to 4.58 conidia $\times 10^{8} \mathrm{~g}^{-1}$ substrate. Additives did not affect conidial production except for reduction by $60 \% \mathrm{D}$-sorbitol, $60 \%$ fructose, and $10 \% \mathrm{CaCl}_{2}$. Conidial dispersal in water improved when $1.5 \%$ sodium alginate was added to substrate in bags before production, and when $1.5 \%$ sodium alginate, $60 \%$ sucrose, $60 \%$ D-sorbitol, $60 \%$ fructose, 5 to $20 \%$ PEG 8000 , or $20 \%$ glycerol were added to conidia before drying. Dispersal of dried conidia was enhanced with $1 \%$ Tween 20, $1 \%$ Tween $80,1 \%$ Trition X-100, 10\% Agral, and 1.5\% sunflower oil. Two P. oxalicum formulations (conidial suspensions maintained with $60 \%$ sucrose or $1.5 \%$ sodium alginate for $10 \mathrm{~min}$ before drying) significantly reduced tomato wilt caused by Fusarium spp. under greenhouse conditions and, in a preliminary trial, by Verticillium spp. in a field assay.
\end{abstract}

Additional keywords: biofungicide, formulation

Penicillium oxalicum Currie \& Thom is a promising fungal agent for biological control of soilborne diseases of tomato $(8,10)$. Application of a conidial suspension of $P$. oxalicum by watering the tomato seedlings in seedbeds 7 days before transplanting usually results in a significant reduction of Fusarium and Verticillium wilts of tomato plants $(7,21)$. Induction of resistance in tomato plants was demonstrated as the main mode of action of $P$. oxalicum against Fusarium oxysporum f. sp. lycopersici (Sacc.) W. C. Snyder \& H. N. Hans. (11). Conidia of $P$. oxalicum must contact the tomato roots $(6,11)$ and a range of $10^{6}$ to $10^{7}$ conidia $\mathrm{g}^{-1}$ in seedbed substrate and rhizosphere before transplanting is required for effective control of wilts of tomato (21).

The main drawback to commercial biocontrol products is the necessity of a shelf-

Corresponding author: P. Melgarejo

E-mail: melgar@inia.es

This research was supported by Project 07M/ 0031/2002 (Comunidad Autónoma de Madrid, Spain), Project AGL2000-0067-P4-03, and Project AGL2004-02161 (Plan Nacional de I+D+I, Ministerio de Educación y Cultura, Spain).

Accepted for publication 15 July 2005.

DOI: 10.1094/PD-89-1317

(C) 2005 The American Phytopathological Society stable formulated product retaining biocontrol activity comparable to fresh cells of the agent (16). Biocontrol of tomato wilt is based on application of $P$. oxalicum conidia (24). A method for mass production of conidia has been developed and conidial applications have reduced wilts of tomato. Unfortunately, viability of these conidia declined within 30 days at room temperature (19). Conidia of P. oxalicum can be dried by fluid bed drying, retaining $100 \%$ viability at the end of the process and 40 to $50 \%$ viability after 180 days of storage at room temperature (20). P. oxalicum conidia dried by fluid bed drying reduced the incidence of Fusarium wilt of tomato under glasshouse and field conditions (20).

An important problem associated with applications of $P$. oxalicum is the hydrophobic nature of conidia, especially of dry conidia (24). For commercial use of $P$. oxalicum, it is essential to enhance conidial dispersal in water, decrease dust hazard (14), reduce settling of conidia and aggregate formation, and thereby improve efficacy of root drenches (15).

The objective of the present study was to evaluate the effect of different additives for dispersal of dried $P$. oxalicum conidia in water, in order to improve the application of the product. Disease control efficacy of the formulated product was tested in glasshouse trials and in a preliminary field trial.

\section{MATERIALS AND METHODS}

Cultures. P. oxalicum (American Type Culture Collection [ATCC] number 201888) was stored on potato dextrose agar (PDA) (Difco Laboratories, Detroit) slants at $4^{\circ} \mathrm{C}$ and grown on PDA in petri dishes in darkness at 20 to $25^{\circ} \mathrm{C}$ for 7 days for inoculum production. Conidia of $P$. oxalicum were produced on peat/ vermiculite/lentil meal $(1 / 1 / 0.5 ; \mathrm{wt} / \mathrm{wt} / \mathrm{wt})$ in plastic bags (19). Mixture (50 g) enclosed in $600-\mathrm{cm}^{3}$ plastic bags was inoculated with $40 \mathrm{ml}$ of a distilled water conidial suspension of $P$. oxalicum $\left(10^{5}\right.$ conidia $\mathrm{g}^{-1}$ of dry substrate), sealed again, and incubated in darkness at 20 to $25^{\circ} \mathrm{C}$ for 5 days. Fresh conidia obtained after incubation were concentrated and resuspended in sterile distilled water for $10 \mathrm{~min}$, and numbers of conidia were estimated with a hemacytometer. Conidial suspensions then were filtered through a 1- $\mu \mathrm{m}$ filter paper using a Büchner funnel. Conidial paste was dried in a fluid bed dryer 350s (Burkard Manufacturing Co Ltd., Hertfordshire, UK) as previously described (20). Conidial moisture content was measured using a humidity analyzer (BOECKEL, GmbH +Co, Hamburg, Germany). Conidia were dried until moisture contents decreased below $10 \%$.

F. oxysporum f. sp. lycopersici race 2 (ATCC number 201829), obtained from a tomato plant in southern Spain, was stored at $4^{\circ} \mathrm{C}$ in tubes containing sterile sand (13). The fungus was grown on Czapek-Dox agar (CDA; Difco Laboratories) in darkness at $25^{\circ} \mathrm{C}$ for mycelial production. Microconidia of $F$. oxysporum f. sp. lycopersici were produced in Czapek-Dox broth (Difco Laboratories) for 5 days at $25^{\circ} \mathrm{C}$ on a rotary shaker at $150 \mathrm{rpm}$ (10). Chlamydospores of $F$. oxysporum f. sp. lycopersici were produced in bags ( 80 by 40 by 20 $\mathrm{cm}^{3}$ ) containing sterile peat. Bags were inoculated with a microconidial suspension in Czapek-Dox broth giving a final density of $10^{5}$ microconidia $\mathrm{g}^{-1}$ of peat, and were left in the glasshouse for 30 days at 20 to $30^{\circ} \mathrm{C}$. At this time, almost all the microconidia became chlamydospores (12). The population of $F$. oxysporum f. sp. lycopersici in the peat was estimated as number of CFU per gram of dry peat employing methods previously described $(7,10,12,21)$.

Plant material. Tomato cv. San Pedro, susceptible to races 1 and 2 of $F$. $o x$ ysporum f. sp. lycopersici and to Verticillium dahliae, were used in all experiments. Tomato seed for glasshouse experiments 
were sown in trays ( 27 by 42 by $7 \mathrm{~cm}^{3}$ ) containing an autoclaved mixture of one part vermiculite and one part peat. The trays were maintained in a growth chamber at 22 to $28^{\circ} \mathrm{C}$ with fluorescent light (100 $\mu \mathrm{E} \mathrm{m} \mathrm{m}^{-2} \mathrm{~s}^{-1}$, 16-h photoperiod) and 80 to $100 \%$ humidity for 3 weeks, then placed in a glasshouse for 7 days before seedlings were transplanted to bags previously inoculated with $F$. oxysporum f. sp. lycopersici as described above.

Tomato seed for field experiments were 4 by $6 \mathrm{~cm} /$ cell) containing an autoclaved mixture of vermiculite and peat as described above. Trays were maintained in a growth chamber for 3 weeks, and then placed in a glasshouse at 20 to $30^{\circ} \mathrm{C}$ for 7 days. Before transplanting into the field, benches close to the field for 2 weeks. Manure was applied to soil approximately 3 months before transplanting in fallowed fields.

Additives. Several compounds such as sugars (sucrose, D-sorbitol, and fructose), polyalcohols (glycerol, polyethylene glycol 300 [PEG 300], PEG 8000, and nonilphenyl-PEG ether [Agral]), inorganic salts $\left(\mathrm{NaCl}, \mathrm{KCl}\right.$, and $\mathrm{CaCl}_{2}$ ), detergents (PEG sorbitan monolaurate [Tween 20], PEG sorbitan monooleate [Tween 80], and mono[p-(1,1,3,3-tetramethylbutyl)

phenyl]-PEG ether [Triton X-100]) were used due to their features as dispersants, sown in trays with 40 individual cells ( 4 by plants were maintained in the trays on

binders, humectants, emulsifiers, and wetters (1). Additives were dissolved in distilled water wt:vol (solids) or vol:vol (liquids) and then autoclaved at $1.0 \mathrm{~kg} \mathrm{~cm}^{-2}$ at $120^{\circ} \mathrm{C}$ for $20 \mathrm{~min}$.

Dispersal assays. Before additives were selected for dispersal assays, the different compounds described above were tested for toxicity (effect on conidial germination and production) against $P$. oxalicum at the dose range previously described $(2,17)$ (Tables 1 to 5). Agral (10\%) was tested as recommended by its manufacturer (Zeneca Agro, Madrid). Three experiments were performed to evaluate the effect of additives on germination of dried conidia of $P$. oxalicum (9). A conidial suspension of $2 \times$ $10^{6}$ conidia $\mathrm{ml}^{-1}$ was prepared in sterile Czapek broth (Difco Laboratories). Additives solutions were prepared as described above at $2 \times$ the dose of those shown in Tables 1 to 5 , except for doses of $60 \%$. Droplets $(15 \mu \mathrm{l})$ of conidial suspensions were mixed on a slide with $15 \mu$ of each additive solution. In the case of $60 \%$ doses (Table 2), each sugar was added to Czapek broth and, after autoclaving at $1.0 \mathrm{~kg} \mathrm{~cm}^{-2}$ at $120^{\circ} \mathrm{C}$ for $20 \mathrm{~min}$, dry conidia of $P$. oxalicum were added to these solutions to give a concentration of $10^{6}$ conidia $\mathrm{ml}^{-1}$. Aliquots of $30 \mu \mathrm{l}$ of each mixture were placed on sterile glass slides. All slides were placed in 15 -cm-diameter glass petri dishes lined with moist paper and incubated for $16 \mathrm{~h}$ at 20 to $25^{\circ} \mathrm{C}$ in darkness.

Table 1. Effect of hydrophobic compounds on germinability of dry conidia and on conidial production of Penicillium oxalicum ${ }^{\mathrm{v}}$

\begin{tabular}{|c|c|c|c|}
\hline $\begin{array}{l}\text { Hydrophobic } \\
\text { compounds, doses }(\%)^{w}\end{array}$ & $\begin{array}{c}\text { Conidia germinated } \\
(\%)^{\mathrm{x}}\end{array}$ & $\begin{array}{c}\text { Germination } \\
\text { enhancement }(\%)^{\mathrm{y}}\end{array}$ & $\begin{array}{l}\text { Production (conidia } \times \\
10^{8} \mathrm{~g}^{-1} \text { of substrate) }\end{array}$ \\
\hline \multicolumn{4}{|l|}{ Sunflower oil } \\
\hline 0 & $71 \mathrm{a}$ & - & $0.57 \mathrm{a}$ \\
\hline 0.1 & $88 \mathrm{bc}$ & 24 & NT \\
\hline 2 & $88 \mathrm{bc}$ & 24 & NT \\
\hline 5 & $95 \mathrm{bc}$ & 34 & NT \\
\hline 10 & $96 \mathrm{c}$ & 36 & $0.81 \mathrm{a}$ \\
\hline 20 & $94 \mathrm{bc}$ & 33 & NT \\
\hline 50 & $85 \mathrm{~b}$ & 20 & NT \\
\hline $\mathrm{MS}_{\text {within }}$ & 58 & $\ldots$ & 0.27 \\
\hline \multicolumn{4}{|l|}{ Sodium alginate } \\
\hline 0 & $61(38) \mathrm{a}$ & - & $0.83(0.23) \mathrm{a}$ \\
\hline 0.1 & $88(64) \mathrm{c}$ & 45 & NT \\
\hline 0.5 & $88(63) \mathrm{c}$ & 45 & NT \\
\hline 1 & $88(63) \mathrm{c}$ & 46 & $1.37(0.31) \mathrm{a}$ \\
\hline 1.5 & $77(51) b$ & 27 & $2.15(0.49) \mathrm{a}$ \\
\hline $\mathrm{MS}_{\text {within }}$ & (94) & $\ldots$ & $(0.03)$ \\
\hline \multicolumn{4}{|l|}{ Methyl cellulose } \\
\hline 0 & $71 \mathrm{a}$ & - & $0.65 \mathrm{a}$ \\
\hline 0.1 & $67 \mathrm{a}$ & - & NT \\
\hline 0.5 & $83 \mathrm{a}$ & - & NT \\
\hline 1 & $77 \mathrm{a}$ & - & NT \\
\hline 1.5 & $72 \mathrm{a}$ & - & $0.76 \mathrm{a}$ \\
\hline $\mathrm{MS}_{\text {within }}$ & 82 & $\ldots$ & 0.32 \\
\hline
\end{tabular}

${ }^{\mathrm{v}}$ Means for each additive followed by the same letter in each column are not significantly different $(P$ $=0.05)$ by Duncan's multiple range test.

${ }^{\mathrm{w}} \mathrm{MS}_{\text {within }}=$ error mean square.

${ }^{\mathrm{x}}$ Data are the mean of three replications; 50 conidia were counted per replication. Data in parentheses were subjected to arcsin transformation before analysis.

${ }^{y}$ All values shown were significantly different from control $(P=0.05)$; - indicates no germination enhancement.

${ }^{\mathrm{z}}$ Data are the mean of three fermentation bags. Data in parentheses were subjected to $\log _{10}(x+1)$ before analysis. NT $=$ not tested.
Germination of 50 conidia was assessed in each replicate and three replicates were made for each sample. A spore was considered germinated when the germ tube was longer than the length of the spore (more than $7 \mu \mathrm{m}$ ).

Two experiments were performed to test the effect of additives on $P$. oxalicum conidial production. Conidia were produced as described above. Substrate contained in plastic bags $(50 \mathrm{~g})$ was inoculated with 40 $\mathrm{ml}$ of a suspension of $P$. oxalicum conidia $\left(10^{5}\right.$ conidia $\mathrm{g}^{-1}$ of dry substrate) in each additive solution (Tables 1 to 5).

To determine the effect of additives on dispersal of $P$. oxalicum conidia, additives were added to conidia at three different steps of the production-drying process (Table 6): (i) to substrate contained in bags before production, (ii) to conidial paste obtained after production before drying, and (iii) to conidia after drying by fluid bed drying. Within each group, the dose tested was the highest nontoxic one, according to the results obtained in toxicity assays (germination and production). Conidia without additives were used as control and three replicates were made per additive and step. For methods $\mathrm{i}$ and ii, conidia were produced and dried as described above and suspended in water; for method iii, an additive solution was used and each was rotated at $150 \mathrm{rpm}$ for $30 \mathrm{~min}$. Dispersal of conidial suspensions or additive solutions was estimated by measuring absorbance at $420 \mathrm{~nm}$ in a spectrophotometer. Three readings were made for each sample and the complete experiment was conducted three times. In each experiment, the percentage of increase of conidial dispersal was calculated by the formula ([dispersal of conidia with additive - dispersal of conidia without additive]/[dispersal of conidia without additive]) $\times 100$.

Glasshouse experiment. Tomato cv. San Pedro plants were used to evaluate the biocontrol efficacy of $P$. oxalicum containing various dispersal additives against $F$. $o x$ ysporum f. sp. lycopersici in April 2003. The following formulations were applied to seedlings in seedbeds, 7 days before transplanting: (i) a conidial suspension of $P$. oxalicum maintained with $60 \%$ sucrose for $10 \mathrm{~min}$ before the drying process (FOR1) and (ii) a conidial suspension of $P$. oxalicum maintained with $1.5 \%$ sodium alginate for $10 \mathrm{~min}$ before the drying process (FOR2). FOR1 and FOR2 were selected in the glasshouse because of good dispersal and germination results obtained previously in preliminary studies. All treatments were made to give $6 \times$ $10^{6}$ spores $\mathrm{g}^{-1}$ of seedbed substrate. Seedlings were transplanted into sterile peat bags ( 80 by 40 by $20 \mathrm{~cm}^{3}$ ) which previously were inoculated with $F$. oxysporum $\mathrm{f}$. sp. lycopersici as described before. Ten tomato plant seedlings were cultivated per bag. Control treatments consisted of plants transplanted into peat with $F$. oxysporum f. sp. lycopersici added without $P$. oxalicum $(\mathrm{C} 1)$ and plants 
transplanted into clean peat $(\mathrm{C} 2)$ with no $P$. oxalicum or $F$. oxysporum added. Five bags per treatment were placed in a glasshouse at 20 to $30^{\circ} \mathrm{C}$ in a randomized block design. Plants were fertilized with Nitrophoska Stabil $14+7+17$ (Basf, Germany) at $100 \mathrm{~g} \mathrm{~m}^{-2}$ 40 days after transplanting. Disease incidence on 50 plants per treatment was recorded at 15, 20, 30, 40, 50, 60, 70, and 80 days after transplanting based on the plants with Fusarium wilt symptoms. The area under the disease progress curve (AUDPC) was calculated (3). The crowns of plants were cut lengthwise and transferred to humid chambers and the presence or absence of $F$. oxysporum f. sp. lycopersici on xylem tissues was determined after 5 days of incubation at 20 to $25^{\circ} \mathrm{C}$. Fungal structures were taken from diseased tissues and were placed on slides, stained with methylene blue, squashed, and examined microscopically. When only mycelia were observed on the diseased tissues, isolations of mycelia on PDA amended with streptomycin sulfate at $0.5 \mathrm{~g} \mathrm{liter}^{-1}$ were made to identify $F$. oxysporum f. sp. lycopersici. Identification was based on presence of chlamydospores formed singly or in pairs, single-cell, oval to kidney-shaped microconidia borne in false heads on short monophialides, and slightly sickle-shaped, thin-walled macroconidia with an attenuated apical cell and a footshaped basal cell (23).

Prior to transplanting (day 7 after treatment), three plants per treatment were selected at random from seedbeds to estimate the population of $P$. oxalicum in the rhizosphere. Population of the fungus also was estimated as described below at the end of the experiment in three plants chosen at random from the 50 plants of each treatment. The roots of each plant were taken from peat, shaken to remove most of the peat, weighed, and added into $250-\mathrm{ml}$ flasks with $150 \mathrm{ml}$ of phosphate buffer $(\mathrm{pH}$ $=7,0.01 \mathrm{M}$ ). Flasks then were rotated for $30 \mathrm{~min}$ at $150 \mathrm{rpm}$, and 10 to 1,000 -fold dilutions were made. Aliquots of $100 \mu \mathrm{l}$ from undiluted and diluted suspensions were spread onto petri dishes containing selective media for $P$. oxalicum (11). Petri dishes were incubated in the dark at $25^{\circ} \mathrm{C}$ for 5 to 7 days, after which the colonies were counted (18). The CFU per plant were calculated per gram of fresh root, plus the peat adhering to the roots, considered to be part of the rhizosphere. Three petri dishes were used per dilution.

Field assay. A field trial was established in a randomized complete block design with five replications (plots) per treatment during the 2003 growing season. The field had a loam soil, $\mathrm{pH}=7.0$, and was located in Aranjuez, Madrid, Spain, where Verticillium wilt disease had been prevalent in previous years (21). Fifteen days after addition of $P$. oxalicum, when the seedlings had four to six leaves, they were carefully transplanted into the field. Ten tomato seedlings of cv. San Pedro per rep- lication or 50 plants per treatment were transplanted on 20 May in $24-\mathrm{m}^{2}$ plots spaced $1 \mathrm{~m}$ within rows with $1.2 \mathrm{~m}$ between rows. The field received a manure treatment about 3 months before planting. During the growing season, tomato plants were flood irrigated as necessary. Tomato plants received two applications of insecticide (Ometoato 50\% p/v [SL], FOLIMAT 50LS; Bayer Hispania S.A., Barcelona, Spain) on 18 June and 2 July. Plots were mechanically cultivated as needed to remove weeds. Tomato plants were treated in seedbeds with the same formulations of $P$. oxalicum described for glasshouse experiment (FOR1 and FOR2). The control treatment had no P. oxalicum applied (C1). Disease incidence was recorded every 15 days for 120 days and symptoms characteristic of wilts of tomato were recorded. The AUDPC was calculated (3). To determine the cause of wilting, aerial parts of all wilted plants were transferred to humidity chambers in the laboratory and the presence or absence of fungal pathogens on them was determined after 5 days of incubation at 20 to $25^{\circ} \mathrm{C}$. Fungal structures were taken from the vegetative tissues to be observed under the microscope as described above for the glasshouse experiment. When only mycelia were observed, fungi were isolated in PDA amended with streptomycin sulfate at $0.5 \mathrm{~g} \mathrm{liter}^{-1}$.

Three plants per treatment were selected at random from seedbeds to estimate $P$. oxalicum population in the rhizosphere, just before transplanting into the field, as described above.

Data analysis. Data were analyzed by analysis of variance (ANOVA) with the Statgraphics Plus 4.1 program. Prior to analysis, some data were subjected to various transformations to improve homogeneity of variances: arcsin for data of conidial germination with sodium alginate, sucrose, fructose, D-sorbitol, glycerol, PEG 300 , PEG 8000, calcium chloride, and Triton TX-100; $\cos 10^{-1}$ for data of conidial germination with Tween 20 ; $\left(\log _{10}+1\right)$ for data of conidial production with fructose, D-sorbitol, PEG 300, and calcium chloride, and for data of percentage of increase of conidial dispersal with all the additives; and cos for data of CFU of P. oxalicum $\mathrm{g}^{-1}$ of fresh root in the field experiment. Germination and production of conidia experiments were repeated with similar results. Dispersal experiments were repeated three times. These three experiments showed similar results. An ANOVA was

Table 2. Effect of sugars on germinability of dry conidia and conidial production of Penicillium oxalicum $^{\mathrm{v}}$

\begin{tabular}{|c|c|c|c|}
\hline $\begin{array}{l}\text { Sugars, } \\
\text { doses }(\%)^{\mathrm{w}}\end{array}$ & $\begin{array}{l}\text { Conidia germinated } \\
\qquad(\%)^{\mathrm{x}}\end{array}$ & $\begin{array}{c}\text { Germination } \\
\text { enhancement }(\%)^{y}\end{array}$ & $\begin{array}{l}\text { Production (conidia } \times \\
10^{8} \mathrm{~g}^{-1} \text { of substrate) }\end{array}$ \\
\hline \multicolumn{4}{|l|}{ Sucrose } \\
\hline 0 & $70(45) \mathrm{a}$ & - & $0.70 \mathrm{a}$ \\
\hline 0.1 & 69 (44) a & - & NT \\
\hline 0.5 & $82(57) b$ & 17 & NT \\
\hline 1 & $80(55) a b$ & - & NT \\
\hline 2 & $71(47) \mathrm{ab}$ & - & NT \\
\hline 15 & $83(58) \mathrm{b}$ & 20 & NT \\
\hline 30 & $95(75) \mathrm{c}$ & 37 & NT \\
\hline 60 & $93(70) \mathrm{c}$ & 33 & $0.61 \mathrm{a}$ \\
\hline $\mathrm{MS}_{\text {within }}$ & (197) & $\ldots$ & 0.31 \\
\hline \multicolumn{4}{|l|}{ D-sorbitol } \\
\hline 0 & $70 \mathrm{a}$ & - & $2.52(0.27) \mathrm{a}$ \\
\hline 0.1 & $74 \mathrm{ab}$ & - & NT \\
\hline 0.5 & $71 \mathrm{a}$ & - & NT \\
\hline 1 & $78 \mathrm{abc}$ & - & NT \\
\hline 2 & $72 \mathrm{ab}$ & - & NT \\
\hline 15 & $81 a b c$ & - & NT \\
\hline 30 & $85 \mathrm{bc}$ & 22 & NT \\
\hline 60 & $90 \mathrm{c}$ & 29 & $0.13(-0.69) b$ \\
\hline $\mathrm{MS}_{\text {within }}$ & 256 & $\ldots$ & $(0.14)$ \\
\hline \multicolumn{4}{|l|}{ Fructose } \\
\hline 0 & $67(45) a b$ & - & $4.58(0.73) \mathrm{a}$ \\
\hline 5 & 78 (54) b & - & NT \\
\hline 10 & $78(54) \mathrm{b}$ & - & NT \\
\hline 20 & 78 (54) b & - & NT \\
\hline 30 & $72(48) b$ & _- & NT \\
\hline 60 & 44 (29) a & - & $0.28(0.10) b$ \\
\hline $\mathrm{MS}_{\text {within }}$ & $(223)$ & $\ldots$ & (0.009) \\
\hline
\end{tabular}

${ }^{\mathrm{v}}$ Means for each additive followed by the same letter in each column are not significantly different $(P$ $=0.05$ ) by Duncan's multiple range test.

${ }^{\mathrm{w}} \mathrm{MS}_{\mathrm{within}}=$ error mean square.

${ }^{x}$ Data are the mean of three replications; 50 conidia were counted per replication. Data in parentheses were subjected to arcsin transformation before analysis.

${ }^{y}$ All values shown were significantly different from control $(P=0.05) ;-$ indicates no germination enhancement.

${ }^{z}$ Data are the mean of three fermentation bags. Data in parentheses were subjected to $\log _{10}(x+1)$ before analysis. NT $=$ not tested. 

factor assay was not significant $(P=0.05)$, a pool of data from each assay was made and further analyzed by ANOVA with nine replications (three experiments with three replications each). When the $F$ test was significant at $P=0.05$ or $P=0.01$, means were compared by Duncan's multiple range test (25).

\section{RESULTS}

Dispersal assays. Toxicity of additives to $P$. oxalicum conidia was tested by effects on germination and production (Tables 1 to 5). Germination of conidia without additives ranged from 51 to $79 \%$ (Tables 1 to 5). Additives assayed did not significantly $(P=0.05)$ reduce conidial germination except for 50\% PEG 300 and $10 \% \mathrm{CaCl}_{2}$ (Tables 1 to 5 ). Several additives significantly $(P=0.05)$ enhanced germination of $P$. oxalicum conidia. These included all doses of sunflower oil and sodium alginate (Table 1); $0.5,15,30$, and $60 \%$ sucrose; 30 and $60 \%$ D-sorbitol (Table 2); 2, 5, 20, and 30\% glycerol; $30 \%$ PEG 300 (Table 3); 0.01 to $1 \% \mathrm{CaCl}_{2}$ (Table 4); made with all three assays and, because the

$0.01,0.02,0.5$, and $1 \%$ Tween 20; and 0.01 to $1 \%$ Tween 80 (Table 5). No effect was observed on conidial germination with methylcellulose, fructose, PEG 8000, Agral, $\mathrm{NaCl}, \mathrm{KCl}$, or Triton TX-100 (Tables 1 to 5).

Production of $P$. oxalicum conidia without additives ranged from 0.57 to 4.58 conidia $\times 10^{8} \mathrm{~g}^{-1}$ of substrate (Tables 1 to $5)$. Additives did not have an effect on conidial production of $P$. oxalicum, except for reductions observed for $60 \% \mathrm{D}$ sorbitol, $60 \%$ fructose, and $10 \% \mathrm{CaCl}_{2}$ (Tables 2 and 4). Conidial production was not significantly enhanced for the additives tested.

Additives with no effects on germination or production of $P$. oxalicum conidia were further tested to improve conidial dispersal. In the first step, additives were added to substrate in bags before production. Sodium alginate at $1.5 \%$ provided higher percentages of conidial dispersal but was not significantly different from 12 other additives (Table 6). Other additives tested did not significantly enhance the dispersal of conidia in water.

Table 3. Effect of polyalcohols on germinability of dry conidia and on conidial production of Penicillium oxalicum ${ }^{\mathrm{v}}$

\begin{tabular}{|c|c|c|c|}
\hline $\begin{array}{l}\text { Polyalcohols, } \\
\text { doses }(\%)^{\mathrm{w}}\end{array}$ & $\begin{array}{c}\text { Conidia germinated } \\
\qquad(\%)^{x}\end{array}$ & $\begin{array}{c}\text { Germination } \\
\text { enhancement }(\%)^{y}\end{array}$ & $\begin{array}{l}\text { Production (conidia } \times \\
10^{8} \mathrm{~g}^{-1} \text { of substrate) }\end{array}$ \\
\hline \multicolumn{4}{|l|}{ Glycerol } \\
\hline 0 & $68(43) a$ & - & $0.76 \mathrm{a}$ \\
\hline 0.1 & $82(56) a b$ & - & NT \\
\hline 0.5 & $81(55) \mathrm{ab}$ & - & NT \\
\hline 2 & $97(78) \mathrm{c}$ & 38 & NT \\
\hline 5 & $93(73) \mathrm{c}$ & 37 & $1.34 \mathrm{a}$ \\
\hline 20 & $98(80) \mathrm{c}$ & 43 & $0.86 \mathrm{a}$ \\
\hline 30 & $90(65) b c$ & 33 & NT \\
\hline 50 & $78(53) a b$ & - & NT \\
\hline $\mathrm{MS}_{\text {within }}$ & (111) & $\ldots$ & 0.34 \\
\hline \multicolumn{4}{|l|}{ PEG 300} \\
\hline 0 & $76(53) b$ & - & $2.73(0.51) \mathrm{a}$ \\
\hline 5 & $84(60) b$ & - & $2.47(0.45) \mathrm{a}$ \\
\hline 10 & $77(53) \mathrm{b}$ & - & NT \\
\hline 20 & $84(61) b c$ & - & $1.95(0.38) \mathrm{a}$ \\
\hline 30 & $92(72) \mathrm{c}$ & 25 & NT \\
\hline 40 & $88(65) b c$ & - & NT \\
\hline 50 & $56(36) \mathrm{a}$ & - & NT \\
\hline $\mathrm{MS}_{\text {within }}$ & (131) & $\ldots$ & $(0.07)$ \\
\hline \multicolumn{4}{|l|}{$\begin{array}{l}\text { PEG8000 } \\
\text { PEthin }\end{array}$} \\
\hline 0 & $79(55) \mathrm{a}$ & - & $1.32 \mathrm{a}$ \\
\hline 5 & $79(55) \mathrm{a}$ & - & $1.47 \mathrm{a}$ \\
\hline 10 & $82(56) \mathrm{a}$ & - & NT \\
\hline 20 & $92(70) \mathrm{a}$ & - & $2.02 \mathrm{a}$ \\
\hline 30 & $94(73) \mathrm{a}$ & - & NT \\
\hline 40 & $94(71) \mathrm{a}$ & - & NT \\
\hline 50 & 89 (67) a & - & NT \\
\hline $\mathrm{MS}_{\text {within }}$ & $(176)$ & $\ldots$ & 0.30 \\
\hline \multicolumn{4}{|l|}{ Agral } \\
\hline 0 & $51.3 \mathrm{a}$ & - & $4.58 \mathrm{a}$ \\
\hline 10 & $32.2 \mathrm{a}$ & - & $5.03 \mathrm{a}$ \\
\hline $\mathrm{MS}_{\text {within }}$ & 161.1 & $\ldots$ & 2.19 \\
\hline
\end{tabular}

${ }^{\mathrm{v}}$ Means for each additive followed by the same letter in each column are not significantly different $(P$ $=0.05)$ by Duncan's multiple range test.

${ }^{\mathrm{w}} \mathrm{MS}_{\text {within }}=$ error mean square.

${ }^{\mathrm{x}}$ Data are the mean of three replications; 50 conidia were counted per replication. Data in parentheses were subjected to arcsin transformation before analysis.

${ }^{y}$ All values shown were significantly different from control $(P=0.05)$; - indicates no germination enhancement.

${ }^{\mathrm{z}}$ Data are the mean of three fermentation bags. Data in parentheses were subjected to $\log _{10}(x+1)$ before analysis. NT $=$ not tested.
Five additives significantly $(P=0.05)$ increased the dispersal of conidial suspensions when they were added to conidia before drying. These included $1.5 \%$ sodium alginate, $60 \%$ sucrose, $60 \% \mathrm{D}$ sorbitol, $60 \%$ fructose, and 20\% PEG 8000 (Table 6).

Once conidia were dried, their dispersal in water was only enhanced when suspended in detergent solutions such as $1 \%$ Triton X-100 and 10\% Agral (Table 6).

Glasshouse experiment. Tomato plants without $P$. oxalicum added showed symptoms of Fusarium wilt 15 days after transplanting, and $55 \%$ of the plants were diseased 80 days after transplanting. At this time, old leaves drooped and curved downward, and some were yellow. The plants had fewer leaves, frequently wilted, and were stunted. At the end of the assay, only $F$. oxysporum $\mathrm{f}$. sp. lycopersici were observed and isolated from the vascular system of plants. Initial population of $F$. oxysporum $\mathrm{f}$. $\mathrm{sp}$. lycopersici in the soil just before transplanting was $1.37 \times 10^{6} \mathrm{CFU}$ $\mathrm{g}^{-1}$ dry weight. After 80 days, control plants (C2) were healthy and vigorous, although $4 \%$ were diseased. When infection was detected in control plants, the assay was concluded (80 days after transplanting).

Use of FOR2 reduced tomato wilt incidence and AUDPC at the end of the experiment (Table 7). FOR1 only reduced tomato wilt incidence but did not significantly reduce AUDPC.

The population of $P$. oxalicum in the rhizosphere of seedlings 7 days after treatment with formulations was higher than $10^{6} \mathrm{CFU} \mathrm{g}^{-1}$ of fresh root in all cases (Table 7). The highest population was obtained in rhizosphere of plants treated with FOR2, 20 times more than with FOR 1. In the case of control plots ( $\mathrm{C} 1$ and C2, nontreated with $P$. oxalicum), some populations of $P$. oxalicum were isolated, in both cases less than $10^{3} \mathrm{CFU} \mathrm{\textrm {g } ^ { - 1 }}$ of fresh root. The population of $P$. oxalicum decreased to levels close to $10^{3} \mathrm{CFU} \mathrm{g}^{-1}$ of fresh root at the end of assay. For the controls, $\mathrm{C} 1$ and $\mathrm{C} 2$, a population of $P$. oxalicum was not detected at the end of assay (Table 7).

Field assay. In the field experiment at 57 days after treatment, initial symptoms included mature leaves that were drooping, curved downward, and chlorotic. A total of 26 plants wilted after 120 days of transplanting (51\% incidence; Table 8 ) in the control treatment; Verticillium spp. were isolated from all of these plants. $F$. oxysporum f. sp. lycopersici also was isolated from four plants. The treatments FOR1 and FOR2 reduced tomato wilt incidence 22 and $14 \%$, respectively, and AUDPC at the end of the experiment (Table 8).

No differences were observed between just before transplanting and 15 days after treatment in the populations of $P$. oxalicum 
estimated on tomato rhizosphere in any treatment (Table 8).

\section{DISCUSSION}

P. oxalicum has shown a good potential for development as a commercial biocontrol product (21). Nondusty, highly miscible, wettable-powder formulations of $P$. oxalicum conidia were developed by adding compounds at one of three different steps of the production-formulation process.

Problems with conidial suspension in water of $P$. oxalicum, particularly after the drying process, were addressed $(20,24)$. Dusty powders, such as conidia that form dry aggregates, result in mixtures with aggregates that settle when added to water and produce irregular distribution in applications with erratic control (2). These aggregates also obstruct nozzles in spray tanks (2). Several additives were tested in this study to overcome these drawbacks.

Hydrophobic compounds, such as sugars, polyalcohols, inorganic salts, and detergents, were used as dispersal additives. Detergents added in this study to suspend dried conidia in water just before application enhanced dispersal of conidia. Detergents helped to reduce surface tension at the liquid-solid interface and facilitated air distribution around particles (17).

Additives should not affect production and germination of conidia. Dispersal assays were carried out with additives at doses that had no effect on conidial production or germinability. In these assays, conidia were germinated in Czapek-Dox broth, a complete medium conducive to germination of conidia, as observed in the controls without additives. Several doses of some additives (Tables 1 to 5) enhanced germination of $P$. oxalicum conidia in these conditions; therefore, these additives may improve water and nutrient absorption of $P$. oxalicum conidia. Water and nutrients are essential, together with gas ratios and favorable temperature, in rehydration of conidia to activate certain enzyme systems, to initiate other internal chemical changes, and to increase the volume of germinating spores $(5,22,26)$. However, there could be a negative effect of additives. If all spores are induced to germinate by the additive, there will be no spore reserves in the mix, because spores that are induced to germinate and are not in the root niche will die.

The best results on dispersal of conidia were obtained when additives (glycerol, PEG 8000, sodium alginate, and sugars) were added to conidia before drying. These compounds form hydrogen bonds with functional groups of protein molecules on dry conidia surfaces $(4,24,27)$ and allow rehydration and improve dispersal by reducing the hydrophobicity of conidial surfaces of $P$. oxalicum. Conidial dispersal also was enhanced when sodium alginate was added to the substrate. These studies demonstrate that adding additives to the
Table 4. Effect of inorganic salts on germinability of dry conidia and on conidial production of Penicillium oxalicum ${ }^{\mathrm{v}}$

\begin{tabular}{|c|c|c|c|}
\hline $\begin{array}{l}\text { Inorganic salts, } \\
\text { doses }(\%)^{w}\end{array}$ & $\begin{array}{c}\text { Conidia germinated } \\
(\%)^{\mathrm{x}}\end{array}$ & $\begin{array}{c}\text { Germination } \\
\text { enhancement }(\%)^{\mathrm{y}}\end{array}$ & $\begin{array}{l}\text { Production (conidia } \times \\
10^{8} \mathrm{~g}^{-1} \text { of substrate) }\end{array}$ \\
\hline \multicolumn{4}{|l|}{ Sodium chloride } \\
\hline 0 & $74 \mathrm{a}$ & - & $0.98 \mathrm{a}$ \\
\hline 0.5 & $82 \mathrm{a}$ & - & NT \\
\hline 1 & $74 \mathrm{a}$ & - & NT \\
\hline 5 & $77 \mathrm{a}$ & - & NT \\
\hline 10 & $77 \mathrm{a}$ & - & $1.20 \mathrm{a}$ \\
\hline $\mathrm{MS}_{\text {within }}$ & 311 & $\ldots$ & 0.29 \\
\hline \multicolumn{4}{|l|}{ Potassium chloride } \\
\hline 0 & $74 \mathrm{a}$ & - & $0.98 \mathrm{a}$ \\
\hline 0.5 & $75 \mathrm{a}$ & - & NT \\
\hline 1 & $76 \mathrm{a}$ & - & NT \\
\hline 5 & $76 \mathrm{a}$ & - & NT \\
\hline 10 & $76 \mathrm{a}$ & - & $1.06 \mathrm{a}$ \\
\hline $\mathrm{MS}_{\text {within }}$ & 274 & $\ldots$ & 0.17 \\
\hline \multicolumn{4}{|l|}{ Calcium chloride } \\
\hline 0 & $64(42) b$ & - & $2.99(0.57) \mathrm{a}$ \\
\hline 0.01 & $88(68) \mathrm{c}$ & 39 & NT \\
\hline 0.05 & $86(62) \mathrm{c}$ & 35 & NT \\
\hline 0.1 & $88(62) \mathrm{c}$ & 38 & NT \\
\hline 0.5 & $93(69) \mathrm{c}$ & 46 & NT \\
\hline 1 & $88(63) \mathrm{c}$ & 37 & NT \\
\hline 10 & $26(16) \mathrm{a}$ & - & $1.40(0.37) b$ \\
\hline $\mathrm{MS}_{\text {within }}$ & $(186)$ & $\ldots$ & $(0.021)$ \\
\hline
\end{tabular}

${ }^{\mathrm{v}}$ Means for each additive followed by the same letter in each column are not significantly different $(P$ $=0.05$ ) by Duncan's multiple range test.

${ }^{\mathrm{w}} \mathrm{MS}_{\text {within }}=$ error mean square.

${ }^{x}$ Data are the mean of three replications; 50 conidia were counted per replication. Data in parentheses were subjected to arcsin transformation before analysis.

y All values shown were significantly different from control $(P=0.05)$; - indicates no germination enhancement.

${ }^{z}$ Data are the mean of three fermentation bags. Data in parentheses were subjected to $\log _{10}(x+1)$ before analysis. $\mathrm{NT}=$ not tested.

Table 5. Effect of non-ionic surfactants on germinability of dry conidia and on conidial production of Penicillium oxalicum ${ }^{\mathrm{v}}$

\begin{tabular}{|c|c|c|c|}
\hline $\begin{array}{l}\text { Detergents, } \\
\text { doses }(\%)^{\mathrm{w}}\end{array}$ & $\begin{array}{l}\text { Conidia germinated } \\
(\%)^{\mathrm{x}}\end{array}$ & $\begin{array}{c}\text { Germination } \\
\text { enhancement }(\%)^{y}\end{array}$ & $\begin{array}{l}\text { Production (conidia } \times \\
10^{8} \mathrm{~g}^{-1} \text { of substrate) }\end{array}$ \\
\hline \multicolumn{4}{|l|}{ Tween 20} \\
\hline 0 & $70(0.992) \mathrm{a}$ & - & $0.87 \mathrm{a}$ \\
\hline 0.01 & $81(0.989) \mathrm{b}$ & 16 & NT \\
\hline 0.02 & $84(0.989) \mathrm{b}$ & 21 & NT \\
\hline 0.3 & $80(0.990) \mathrm{ab}$ & - & NT \\
\hline 0.5 & $82(0.989) \mathrm{b}$ & 18 & NT \\
\hline 1 & $85(0.988) b$ & 21 & $0.97 \mathrm{a}$ \\
\hline $\mathrm{MS}_{\text {within }}$ & $\left(8 \times 10^{-6}\right)$ & $\ldots$ & 0.13 \\
\hline \multicolumn{4}{|l|}{ Tween 80} \\
\hline 0 & $71 \mathrm{a}$ & - & $0.97 \mathrm{a}$ \\
\hline 0.01 & $87 \mathrm{~b}$ & 23 & NT \\
\hline 0.02 & $89 \mathrm{bc}$ & 25 & NT \\
\hline 0.3 & $95 \mathrm{c}$ & 34 & NT \\
\hline 0.5 & $94 \mathrm{bc}$ & 32 & NT \\
\hline 1 & $94 \mathrm{c}$ & 33 & $1.21 \mathrm{a}$ \\
\hline $\mathrm{MS}_{\text {within }}$ & 39 & $\ldots$ & 0.24 \\
\hline \multicolumn{4}{|l|}{ Triton TX-100 } \\
\hline 0 & $74(50) \mathrm{a}$ & - & $0.80 \mathrm{a}$ \\
\hline 0.01 & 77 (54) a & - & NT \\
\hline 0.02 & $85(60) \mathrm{a}$ & - & NT \\
\hline 0.3 & $86(61)$ a & - & NT \\
\hline 0.5 & $86(61) a$ & - & NT \\
\hline 1 & $84(59)$ a & - & $0.83 \mathrm{a}$ \\
\hline $\mathrm{MS}_{\text {within }}$ & (184) & $\ldots$ & 0.14 \\
\hline
\end{tabular}

${ }^{\mathrm{v}}$ Means for each additive followed by the same letter in each column are not significantly different $(P$ $=0.05$ ) by Duncan's multiple range test.

${ }^{\mathrm{w}} \mathrm{MS}_{\text {within }}=$ error mean square.

${ }^{x}$ Data are the mean of three replications; 50 conidia were counted per replication. Data were subjected to cos/10 and arcsin for Tween 20 and Triton TX-100, respectively, before analysis.

${ }^{\mathrm{y}}$ All values shown were significantly different from control $(P=0.05)$; - indicates no germination enhancement.

${ }^{\mathrm{z}}$ Data are the mean of three fermentation bags. NT $=$ not tested. 
Table 6. Effect of different additives added before production, before drying process, and to dry conidia, on conidial dispersal of Penicillium oxalicum ${ }^{\mathrm{y}}$

\begin{tabular}{lccl}
\hline Additives $^{\mathbf{z}}$ & Before production & Before drying & After drying \\
\hline $1.5 \%$ Sunflower oil & $1.20 \mathrm{ab}$ & $0.54 \mathrm{abc}$ & $1.20 \mathrm{cde}$ \\
$1.5 \%$ Sodium alginate & $1.44 \mathrm{~b}$ & $1.98 \mathrm{c}$ & $0.53 \mathrm{abcd}$ \\
$1.5 \%$ Methyl cellulose & $1.08 \mathrm{ab}$ & $1.08 \mathrm{abc}$ & $0.21 \mathrm{ab}$ \\
$60 \%$ Sucrose & $0.50 \mathrm{ab}$ & $1.82 \mathrm{c}$ & $0.00 \mathrm{a}$ \\
$60 \%$ D-sorbitol & $\mathrm{NT}$ & $1.80 \mathrm{c}$ & $0.00 \mathrm{a}$ \\
$60 \%$ Fructose & $\mathrm{NT}$ & $1.90 \mathrm{c}$ & $0.00 \mathrm{a}$ \\
$5 \%$ Glycerol & $0.51 \mathrm{ab}$ & $0.82 \mathrm{abc}$ & $0.00 \mathrm{a}$ \\
$20 \%$ Glycerol & $0.73 \mathrm{ab}$ & $1.74 \mathrm{bc}$ & $0.00 \mathrm{a}$ \\
$5 \%$ PEG300 & $0.13 \mathrm{a}$ & $0.00 \mathrm{a}$ & $0.00 \mathrm{a}$ \\
$20 \%$ PEG300 & $0.00 \mathrm{a}$ & $0.98 \mathrm{abc}$ & $0.00 \mathrm{a}$ \\
$5 \%$ PEG8000 & $1.18 \mathrm{ab}$ & $1.62 \mathrm{bc}$ & $0.35 \mathrm{abc}$ \\
$20 \%$ PEG8000 & $1.17 \mathrm{ab}$ & $1.84 \mathrm{c}$ & $0.00 \mathrm{a}$ \\
$10 \%$ Agral & $1.15 \mathrm{ab}$ & $0.20 \mathrm{ab}$ & $1.46 \mathrm{e}$ \\
$10 \%$ NaCl & $0.47 \mathrm{ab}$ & $0.00 \mathrm{a}$ & $0.69 \mathrm{abcde}$ \\
$10 \%$ KCl & $0.75 \mathrm{ab}$ & $0.00 \mathrm{a}$ & $0.00 \mathrm{a}$ \\
$1 \%$ Tween 20 & $0.79 \mathrm{ab}$ & $0.47 \mathrm{abc}$ & $0.96 \mathrm{bcde}$ \\
$1 \%$ Tween 80 & $0.00 \mathrm{a}$ & $1.18 \mathrm{abc}$ & $1.32 \mathrm{de}$ \\
$1 \%$ Triton X-100 & $0.62 \mathrm{ab}$ & $0.61 \mathrm{abc}$ & $1.47 \mathrm{e}$ \\
$\mathrm{MS}$ within & 0.39 & 0.25 & 0.20 \\
\hline
\end{tabular}

${ }^{y}$ Data are $\log _{10}(x+1)$ percentage of increase of conidial dispersal and were calculated by the formula $\log _{10}(x+1)$ where $x=$ ([dispersal of conidia with additive - dispersal of conidia without additive]/[dispersal of conidia without additive] $) \times 100$. Dispersal of conidia suspensions was measured as absorbance at $420 \mathrm{~nm}$ in a spectrophotometer. Data are the mean of three experiments with three replications in each experiment (nine replications). Means for each additive followed by the same letter in each column are not significantly different $(P=0.05)$ by Duncan's multiple range test; NT $=$ treatments not tested.

${ }^{\mathrm{z}}$ Additives were added to (i) substrate contained in bags before production, (ii) conidial paste obtained after production before drying, or (iii) conidia after drying by fluid bed drying. $\mathrm{MS}_{\text {within }}=$ error mean square.

Table 7. Disease incidence (percent with Fusarium spp.) on tomato plants treated with Penicillium oxalicum and populations of $P$. oxalicum in the rhizosphere ${ }^{\mathrm{y}}$

\begin{tabular}{lcccc}
\hline & & \multicolumn{2}{c}{$\begin{array}{c}\text { Populations of } \boldsymbol{P} \text { oxalicum in rhizosphere } \\
\left(\times \mathbf{1 0}^{\mathbf{3}} \mathbf{C F U} \mathbf{~ g}^{\mathbf{- 1}} \text { of fresh root }\right)\end{array}$} \\
\cline { 4 - 5 } Treatments $^{\mathbf{z}}$ & Disease incidence & AUDPC & $\begin{array}{c}\text { Before transplanting } \\
\text { EOnd of assay }\end{array}$ \\
\hline FOR1 & $22.0 \mathrm{c}$ & $970 \mathrm{ab}$ & $3,697 \mathrm{a}$ & $11.0 \mathrm{a}$ \\
FOR2 & $26.9 \mathrm{bc}$ & $855 \mathrm{~b}$ & $85,528 \mathrm{~b}$ & $5.0 \mathrm{a}$ \\
$\mathrm{C} 1$ & $55.4 \mathrm{a}$ & $1,569 \mathrm{a}$ & $<10^{3}$ & $\mathrm{ND}$ \\
$\mathrm{C} 2$ & $4.0 \mathrm{c}$ & $130 \mathrm{c}$ & $<10^{3}$ & $\mathrm{ND}$ \\
MS $_{\text {within }}$ & 260.1 & 240,663 & $5.3 \times 10^{10}$ & $1.96 \times 10^{4}$
\end{tabular}

y Means followed by the same letter in each column are not significantly different by Duncan's multiple range test at $P=0.05$ (incidence and area under the disease progress curve [AUDPC]), or $P=$ 0.01 (P. oxalicum population). Data of incidence and AUDPC are the mean of five replicates with 10 plants per replicate (50 plants). Data of CFU are the mean of three replicates (three randomly chosen plants per treatment). ND $=$ not detected.

${ }^{\mathrm{z}}$ FOR1 = a conidial suspension of $P$. oxalicum maintained with $60 \%$ sucrose for 10 min before drying process, FOR2 $=$ a conidial suspension of $P$. oxalicum maintained with $1.5 \%$ sodium alginate for $10 \mathrm{~min}$ before drying process, $\mathrm{C} 1=$ no $P$. oxalicum and no additive, all inoculated with $F$. oxysporum f. sp. lycopersici, $\mathrm{C} 2=$ no $P$. oxalicum, no additive and not inoculated, and $\mathrm{MS}_{\mathrm{within}}=$ error mean square.

Table 8. Incidence of Verticillium spp. on tomato cv. San Pedro plants in a field experiment at 120 days after transplanting, and population of Penicillium oxalicum in the rhizosphere just before transplanting

\begin{tabular}{|c|c|c|c|}
\hline Treatments $^{\mathrm{z}}$ & $\begin{array}{c}\text { Incidence of } \\
\text { Verticillium spp. }(\%)\end{array}$ & AUDPC & $\begin{array}{l}\text { P. oxalicum } \mathrm{CFU} \mathrm{\textrm {g } ^ { - 1 }} \text { of } \\
\text { fresh root }\left(\times 10^{3}\right)\end{array}$ \\
\hline FOR1 & $22 b$ & $204 \mathrm{~b}$ & $27,000(0.15) \mathrm{a}$ \\
\hline FOR2 & $14 \mathrm{~b}$ & $335 \mathrm{~b}$ & $11,700(0.22) \mathrm{a}$ \\
\hline $\mathrm{C} 1$ & $51 \mathrm{a}$ & $551 \mathrm{a}$ & $<10^{3}$ \\
\hline $\mathrm{MS}_{\text {within }}$ & 305 & 16,682 & $(0.27)$ \\
\hline
\end{tabular}

${ }^{y}$ Data of incidence are the mean of five replicates with 10 plants per replicate (50 plants). Data of CFU are the mean of three replicates (three randomly chosen plants per treatment), and they were subjected to cos transformation before analysis (data in parentheses). Means followed by the same letter in each column are not significantly different by Duncan's multiple range test $(P=0.05)$ (incidence and area under the disease progress curve [AUDPC]), or $P=0.01$ ( . oxalicum population).

${ }^{\mathrm{z}}$ FOR $1=$ a conidial suspension of $P$. oxalicum maintained with $60 \%$ sucrose for 10 min before drying process, FOR2 = a conidial suspension of $P$. oxalicum maintained with $1.5 \%$ sodium alginate for 10 min before drying process, $\mathrm{C} 1=$ no $P$. oxalicum and no additive, and $\mathrm{MS}_{\text {within }}=$ error mean square. growth substrate significantly improved the ability of conidia of $P$. oxalicum to disperse in water. This approach can have wide and useful applications.

Based on dispersal results, two formulations were tested in glasshouse and field trials. P. oxalicum formulations with $60 \%$ sucrose (FOR1) or $1.5 \%$ sodium alginate (FOR2) added to conidia before drying enhanced both dispersal and germination of FOR1 and FOR2, reduced wilts caused by Fusarium spp. in the greenhouse, and, in a preliminary trial, reduced wilts caused by Verticillium spp. in a field assay. Enhancement of dispersal of conidia increased when suspensions of formulations were made before application. Conidia were suspended in the tank of the sprayer without difficulties because conidial settling was avoided. In addition, without aggregate formation, nozzles were not obstructed.

All the plants from the glasshouse experiment were picked up at the end of the experiment to isolate the fungal pathogens causing wilts. F. oxysporum f. sp. lycopersici was the only fungus isolated from the vascular system of these plants. In the field experiment, Verticillium spp. were isolated from all diseased plants and $F$. oxysporum f. sp. lycopersici was isolated from a few plants.

Population levels of $P$. oxalicum in rhizospheres of tomato plants treated with FOR1 and FOR2 before transplanting were in the range of $10^{6}$ to $10^{7} \mathrm{CFU} \mathrm{g^{-1 }}$ of fresh root for both formulations and were similar to previous greenhouse and field experiments $(7,8,21)$ in which disease reduction of Fusarium and Verticillium wilts of tomato were demonstrated. Disease reduction was obtained with FOR1 and FOR2. The presence of nutrients included in FOR1 (60\% sucrose) or FOR2 (1.5\% sodium alginate) may contribute to enhance biocontrol. Previously, we $(7,8,21)$ have demonstrated that conidia applied together with nutrients enhanced consistency of control. We demonstrated here that $60 \%$ sucrose or $1.5 \%$ sodium alginate, among others, enhanced germination of $P$. oxalicum conidia. Typhula phacorriza formulated as sodium alginate pellets was effective at low rates $\left(20 \mathrm{~g} \mathrm{~m}^{-2}\right)$ to control gray snow mold of turf grass and cereals caused by $T$. incarnata and $T$. ishikariensis in other studies (28). Nutrient bases may enable propagules of biocontrol agents to germinate and colonize the rhizosphere or may be a nutrient base for the antagonist during the early stages of proliferation after application to the soil.

Interplot interference could occur due to flood irrigation in field assays because conidia of $P$. oxalicum may have been moved by water between plots. To reduce this problem, a distance of $1 \mathrm{~m}^{2}$ was established between plants, and plots were established in a randomized block design. In addition, although some conidia from a 
plot were moved to the rhizosphere of plants of another plot, the levels were low, and less than the $10^{6}$ to $10^{7}$ conidia per grams of fresh root necessary to reduce disease (21).

Our results provide an effective method to add additives to the conidial production process or during formulation as a dry product to improve $P$. oxalicum dispersal, increasing disease reduction from wilt of tomato caused by Fusarium and Verticillium spp.

\section{ACKNOWLEDGMENTS}

We thank J. Belmonte and A. Barrionuevo for technical support, and J. Cubero and A. Sztejnberg for helping with English.

\section{LITERATURE CITED}

1. Bernhard, K., Holloway, P. J., and Burges, H. D. 1998. Catalogue of formulation additives: function, nomenclature, properties and suppliers. Pages 333-365 in: Formulation of Microbial Biopesticides. H. D. Burges, ed. Kluwer Academic Publishers, Dordrecht, The Netherlands.

2. Burges, H. D., and Jones, K. A. 1998. Trends in formulation of microorganisms and future research requirements. Pages 311-332 in: Formulation of Microbial Biopesticides. H. D. Burges, ed. Kluwer Academic Publishers, Dordrecht, The Netherlands.

3. Campbell, C. L., and Madden, L. V. 1990. Introduction to Plant Disease Epidemiology. Wiley-Interscience, New York.

4. Carpenter, J. F., Crowe, J. H., and Arakawa, T. 1990. Comparison of solute-induced protein stabilization in aqueous solution and in the frozen and dried states. J. Dairy Sci. 73:36273636.

5. Costa, E., Usall, J., Teixido, N., Garcia, I., and Viñas, I. 2000. Effect of protective agents rehydration media and initial cell concentration on viability of Pantoea agglomerans strain CPA-2 subjected to freeze-drying. J. Appl. Microbiol. 89:793-800.

6. De Cal, A., García-Lepe, R., and Melgarejo, P.
2000. Induced resistance by Penicillium oxalicum against of Fusarium oxysporum f. sp. lycopersici: histological studies of infected and induced tomato stems. Phytopathology 90:260268.

7. De Cal, A., García-Lepe, R., Pascual, S., and Melgarejo, P. 1999. Effects of timing and method of application of Penicillium oxalicum on efficacy and duration of control of Fusarium wilt of tomato. Plant Pathol. 48:260-266.

8. De Cal, A., and Melgarejo, P. 2001. Repeated applications of Penicillium oxalicum prolongs biocontrol of Fusarium wilt of tomato plants. Eur. J. Plant Pathol. 107:805-811.

9. De Cal, A., M-Sagasta, E., and Melgarejo, P. 1988. Antifungal substances produced by Penicillium frequentans and their relationship to the biocontrol of Monilinia laxa. Phytopathology 78:888-893.

10. De Cal, A., Pascual, S., and Melgarejo, P. 1995. Biological control of Fusarium oxysporum f. sp. lycopersici. Plant Pathol. 44:909-914.

11. De Cal, A., Pascual, S., and Melgarejo, P. 1997. Involvement of resistance induction by Penicillium oxalicum in the biocontrol of tomato wilt. Plant Pathol. 46:72-79.

12. De Cal, A., Pascual, S., and Melgarejo, P. 1997. Infectivity of chlamydospores vs. microconidia of Fusarium oxysporum f. sp. lycopersici on tomato. J. Phytopathol. 145:231-233.

13. Delcán, J., Moyano, C., Raposo, R, and Melgarejo, P. 2002. Storage of Botrytis cinerea using different methods. J. Plant Pathol. 84:3-9.

14. Goettel, M. S., and Jaronski, S. T. 1997. Safety and registration of microbial agents for control of grasshoppers and locust. Pages 83-99 in: Microbial Control of Grasshoppers and Locust. Memoirs of the Entomological Society of Canada. M. S. Goettel, and D. L. Johnson, eds. Ottawa, Ontario, Canada.

15. Hallsworth, J. E., and Magan, N. 1996. Culture age, temperature and $\mathrm{pH}$ affect the polyol and trehalose contents of fungal propagules. Appl. Environ. Microbiol. 21:2435-2442.

16. Janisiewicz, W. J., and Jeffers, S. N. 1997. Efficacy of commercial formulation of two biofungicides for control of blue mold and gray mold of apples in cold storage. Crop Prot. 16:629-633.

17. Jones, K. A., and Burges, H. D. 1998.
Techonology of formulation and application. Pages 7-30 in: Formulation of Microbial Biopesticides. H. D. Burges, ed. Kluwer Academic Publishers, Dordrecht, The Netherlands.

18. Lacey, J., Hill, S. T., and Edwards, M. A. 1980. Microorganisms in stored grains: their enumeration and significance. Trop. Stored Prod. Inf. 39:19-33.

19. Larena, I., Melgarejo, P., and De Cal, A. 2002. Production, survival and evaluation of solidsubstrate inocula of Penicillium oxalicum, a biocontrol agent against Fusarium wilt of tomato. Phytopathology 92:863-869.

20. Larena, I., Melgarejo, P., and De Cal, A. 2003. Drying of conidia of Penicillium oxalicum, a biological control agent against Fusarium wilt of tomato. J. Phytopathol. 151:600-606.

21. Larena, I., Sabuquillo, P., Melgarejo, P., and De Cal, A. 2003. Biocontrol of Fusarium and Verticillium wilt of tomato by Penicillium oxalicum under greenhouse and field conditions. J. Phytopathol. 151:507-512.

22. Lilly, V. G., and Barnett, H. L. 1951. Physiology of the Fungi. McGraw-Hill Book Company, Inc., New York.

23. Nelson, P. E., Toussoun, T. A., and Marasas, W. F. O. 1983. Fusarium Species. An Illustrated Manual for Identification. The Pennsylvania State University Press, University Park and London.

24. Pascual, S., De Cal, A., Magan, N., and Melgarejo, P. 2000. Surface hydrophobicity, viability and efficacy in biological control of Penicillium ox alicum spores produced in aerial and submerged culture. J. Appl. Microbiol. 89:847-853.

25. Snedecor, G. W. and Cochran, W. G. 1980. Statistical Methods, 7 th ed. Iowa State University Press, Ames.

26. Stock, D., and Briggs, G. 2000. Physicochemical properties of adjuvants: values and applications. Weed Technol. 14:798-806.

27. Wiencek, K. M., Klapes, N. A., and Foegeding, P. M. 1990. Hydrophobicity of Bacillus and Clostridium spores. Appl. Environ. Microbiol. 56:2600-2605.

28. Wu, C., and Hsiang, T. 1998. Pathogenicity and formulation of Typhula phacorrhiza, a biocontrol agent of gray snow mold. Plant Dis. 82:1003-1006. 